\title{
Anti-Microbial Activities and Phytochemical Screening of the Premna Odorata Blanco (Alagaw) Leaf Extract
}

\author{
Bernadette C. Mollejon, Charito V. Mollejon \\ Department of Physical Sciences, College of Science, University of Eastern Philippines, \\ University Town, Catarman, Northern Samar, Philippines
}

\begin{abstract}
How to cite this paper: Bernadette $\mathrm{C}$. Mollejon | Charito V. Mollejon "AntiMicrobial Activities and Phytochemical Screening of the Premna Odorata Blanco (Alagaw) Leaf Extract" Published in International Journal of Trend in Scientific Research and Development (ijtsrd), ISSN: 24566470, Volume-3 | Issue-4, June 2019, pp.343-345, URL: https://www.ijtsrd.c om/papers/ijtsrd23 751.pdf

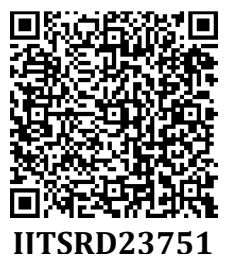

Copyright (C) 2019 by author(s) and International Journal of Trend in Scientific Research and Development Journal. This is an Open Access article distributed under the terms of the Creative Commons


Attribution License (CC BY 4.0) (http://creativecommons.org/licenses/ by $/ 4.0$ )

fruits and leaves are used as active ingredients. The country needs medicinal plants. With proper nutrition, disease prevention and control measures help provide adequate health care to the population and contribute to the improvement of the quality of life. Medicinal plants are need for fresh plants materials and must always be observed in the use.

Premna odorata Blanco was one of the healing plants for Worldwide, cancer causes more deaths than AIDS, tuberculosis and malaria combined although several anticancer drugs already commercially available, a number of adverse effects sometimes occur during chemotherapy. To reduce this unwanted effect many chemotherapeutic agents in the clinic are derived from natural products or designed on the basis of original compounds found in natural product. In the search new cancer chemo preventive agents from natural sources, This research was directed towards the screening of plants with antimutagenic activity in the micronucleus test ( MT) based on the method of schmid, MT is highly sensitive in vivo test designed to detect carcinogenic effects. In addition, this study also focused on the isolation and characterization of the antimutagenic expressions of the plant identified with highest activity using a bioassay directed scheme. As a part of systematic investigation of identifying bioactive compounds from Philippine plant extract was subjected to different investigator. Initiated screens at the institute of chemistry and cell Biology (ICCB) Screening Facility at Harvard Medical School. The selected plants that were selected to the preliminary screening for bioactivity in MT included Premna Odorata Blanco. These plants were chosen since they were among the few plant extract gave positive results in various assays from the Philippine plant extract libraries deposited at the ICCB. The literature search revealed that iridoid glycosides were isolated from Premna Odorata Blanco.

\section{METHODOLOGY}

Calculate the percent yield of the mass of crude extract of leaf over the volume of the leaf extract multiply by one hundred (100) of Premna Odorata Blanco (Alagaw) leaf extract using the formula:

$$
\% \text { yield }=\frac{\text { mags of extract }}{\text { vplume of extract }} \times 100
$$

\section{Test for the presence of alkaloid}

In this test the Dragendorff's reagent and Mayer's reagent was used to test the presence of alkaloid in leaf extract of Premna Odorata Blanco. From cold extract it was separated 
and took $5 \mathrm{ml}$ of leaf extract of Premna Odorata Blanco and was separated in evaporating dish. It was evaporated over a steam bath and added $5 \mathrm{ml}$ of $2 \mathrm{M} \mathrm{HCl}$, heated while stirring for 5 minutes and let was cooled. Then added about $0.5 \mathrm{~g}$ $\mathrm{NaCl}$ stir and filtered, washed the residue with enough $2 \mathrm{M}$ $\mathrm{HCl}$ to bring the filtrate to a volume of the leaves filtrate and treated with Mayer's reagent. The result was recorded. A positive result indicated by orange precipitate with draggendorff's reagent and white precipitate with the Mayer's reagent.

\section{Test for the presence of anthraquinones}

Test for the presence of anthraquinone was done using the procedure provided by Guevarra 2005. The modified Bontragers test was used in determining the presence of Anthraquinone. A pink color indicated a positive of Anthraquinone.

Equivalent of $1 \mathrm{~g}$ extract was evaporated to incident dryness over a steam both, and then $10 \mathrm{ml} 0.5 \mathrm{M}$ potassium hydroxide and $1 \mathrm{ml}$ of $1 \%\left(\mathrm{H}_{2} \mathrm{O}_{2}\right)$ were added and stirred. The resulting mixture was heated over a steam bath for 10 minutes. The residue was filtered and discarded. The filtrate was acidified with glacial acetic acid. The aqueous filtrate was extracted twice in $5 \mathrm{ml}$ portions of benzene (caution: carninogenic!). Combining the benzene extracts and divided the extracts into 2 portions as the control and the other portions was treated with ammonia solutions. The tube was shaken and compared with the control tubes.

\section{Test for the presence of saponin}

The capillary test was used to determine the presence of saponin if the level of the plant extract in capillary tube is half in the other tube containing water, the presence of saponin may be inferred. A capillary tube was loaded with the plant extract by immersing the tube to a height $10 \mathrm{~mm}$ in the plant. Likewise load another capillary tube was loaded with distilled water, the lift capillary tubes and keep both in a vertical position to allow the liquid inside to flow out freely after sometimes the height of the liquid in the two tubes was compared.

Test for the presence of steroid

The lie berman-burchard test was used to detect the presence of steroid especially the unsaturated one. The positive result gave the color of ranging from blue to green, red, pink, or violet because of the presence of steroid skeleton.

About $10 \mathrm{~g}$ of the plant material from the prepared plant extract was used and evaporated to incipient dryness over stream bath and cooled to room temperature to defats the material by taking up the residue with $6 \mathrm{ml}$ of hexane and $3 \mathrm{ml}$ of water and was gently shaked the mixture in a test tube then pipette out the upper layer, after that it was repeated the treatment with hexane after most of the colored pigment has been removed, discarded all the hexane extract properly, there treated the aqueous layer with $10 \mathrm{ml}$ chloroform and gently shake the mixture. It was allowed to stand and pipette the chloroform then dry the chloroform extract by filtering the mixture though about $100 \mathrm{mg}$ anhydrous sodium sulfate hold over dry filter paper, divided it by two portion. One was used for control, and then the other portion was treated with 3 drops of acetic anhydrides then one drop of concentrated sulfuric acid. It was observed for any immediate color change and was let it stand for an hour and was observed if further color was changed.

\section{Preparation of the Bacteria}

The non-pathogenic strain of the E. coli bacteria was used in this study. The bacteria was cultured using an agar in nine (9) petri dishes. It was placed in a dark and warm place.

Get $9.5 \mathrm{~g}$ of Nutrient Agar was distilled into $250 \mathrm{ml}$ of water it was boil into 15 minutes while stirring in $50^{\circ} \mathrm{c}$ then cool, after the preparation of agar it was divided into nine (9) portions using in petri dish and streak a soup of bacteria stir and then put into the petri dish and swirled to spread overly. The extract was distilled with the solvent to get the pure Alagaw extract, distilled in the water as negative control and dissolved $500 \mathrm{mg}$ at clarithromycin capsule in $10 \mathrm{ml}$ water as positive control. It was submerged at the paper disk to the extract positive control and negative control. Putted the paper was put in the disk to the prepared cultured bacteria and then placed in the dark and warm room for $24 \mathrm{hrs}$. at inoculation. After the period the zone of inhibition was measured by centimeters, that is the clearing of the bacteria in the petri dish. All possible result was recorded.

\section{RESULTS AND DISCUSSION}

Table1. Summary on Phytochemical screening Tests

\begin{tabular}{|c|l|c|}
\hline $\begin{array}{c}\text { Physical } \\
\text { Properties }\end{array}$ & \multicolumn{1}{|c|}{ Leaf Extract } & Interpretation \\
\hline Alkaloid & $\begin{array}{l}\text { No Orange precipitate form when treated with Dragendorff's reagent and no white } \\
\text { precipitate with Mayer's reagent }\end{array}$ & Negative \\
\hline Anthraquinone & All trials has no pink color observed & Negative \\
\hline Saponin & Lower than in the other water tube containing water & Negative \\
\hline Steroid & No production of range in colors from blue to green, red, pink, violet or purple & Negative \\
\hline
\end{tabular}

It is implicit that all trials in the secondary metabolites such as alkaloid, anthraquinone, steroid and saponin and steroid in alagaw extract is negative.

\begin{tabular}{|c|c|c|c|c|}
\hline & $\begin{array}{c}\text { Negative } \\
\text { Control }\end{array}$ & Positive Control & Alagaw Extract & Interpretation \\
\hline E. Coli & No Inhibition & $\begin{array}{c}\text { Trial 1 \& 3 is 20mm Inhibition } \\
\text { and Trial 2 is 22 Inhibition }\end{array}$ & $\begin{array}{c}\text { Trial 1 \& 3 is 6mm Inhibition and } \\
\text { Trial 2 is no inhibition }\end{array}$ & Negative \\
\hline
\end{tabular}

The Anti-Microbial Property for the E. Coli bacteria tested was found negative in alagaw leaf Extract since the zone of inhibition was found to be less than $20 \mathrm{~mm}$ as stated by Lalitha MK (2004). 


\section{CONCLUSIONS}

Based on the results of the study, the following conclusions were drawn by the researcher: Alagaw leaf has $11.5 \%$ percent yield. Alagaw leaf extract does not contains secondary metabolites called alkaloid, steroid saponin,athraquinone. Even though there is a zone of inhibition, the alagaw extract has no antimicrobial resistance against E. coli.

\section{References}

[1]. Guevara BQ. 2005. A Guide Book to Plant Screening Phytochemical and Biological. Revised Editiion. Espana, Manila University of Santo Tomas Publishing House.

[2]. Lalitha MK. 2004. Manual on Antimicrobial Suspectibility Testing. Indian Association of Medical Microbiologist, Christian Medical College, Tamil Nadu.

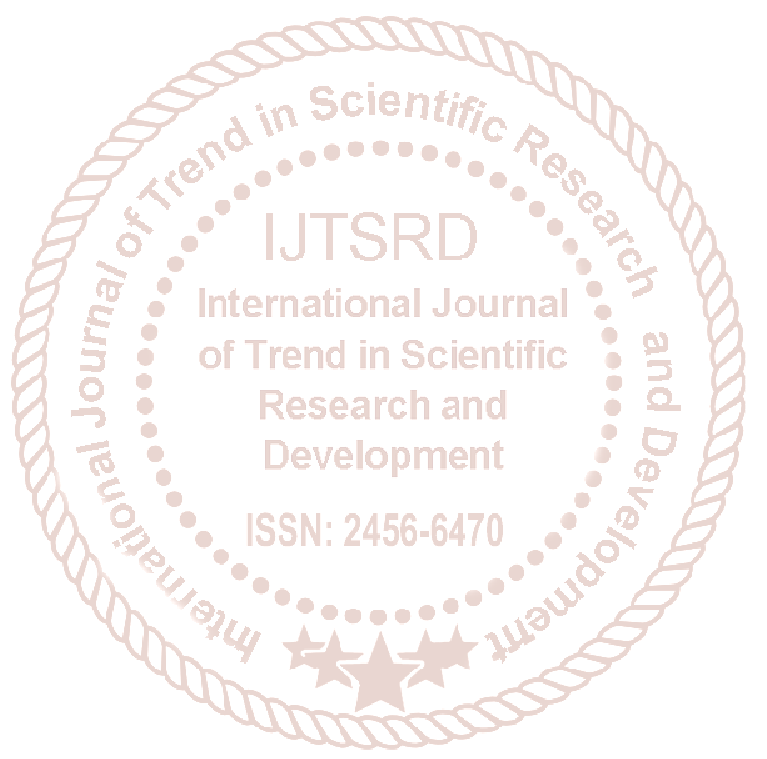

